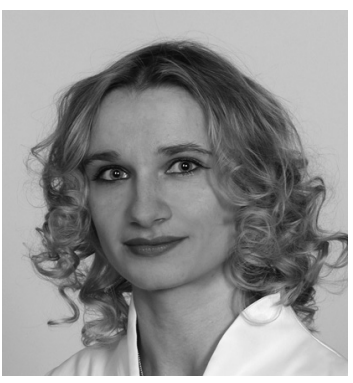

Monika Kulesza-Gierat

Monika Kulesza-Gierat - doktor nauk humanistycznych w zakresie literaturoznawstwa, magister historii sztuki, adiunkt w Katedrze Literatury Oświecenia i Romantyzmu Katolickiego Uniwersytetu Lubelskiego. Opublikowała monografię Aniołowie w poezji Adama Mickiewicza (2007). Zainteresowania badawcze: problematyka teologiczno-filozoficzna w literaturze, korespondencji sztuk ze szczególnym uwzględnieniem powiązań literatury i sztuk plastycznych. 


\title{
Stefana Grabińskiego „traktat” o duszach czyśćcowych
}

\author{
GUSTAW \\ Więc żadnych nie ma duchów? \\ (z ironia) \\ Świat ten jest bez duszy? \\ A. Mickiewicz, Dziady, cz. IV
}

edna z nowel Stefana Grabińskiego zamieszczona w tomie Księga ognia nosi nieco tajemniczy tytuł Muzeum dusz czyśćcowych. Już sam tytuł owej noweli wprowadza nas w charakterystyczny klimat twórczości Grabińskiego, będącej eksploracją pełnej niesamowitych tajemnic pozornie stabilnej, codziennej rzeczywistości, w której pęknięciach prześwitują jednak najzupełniej odmienne światy. To na temat twórczości Grabińskiego Artur Hutnikiewicz skreślił znamienne słowa, iż cała uwaga pisarza napięta jest i wytężona ku „tamtej stronie”, wszystka myśl twórcza i wyobraźnia fantasty skierowane ku jednemu zadaniu, „by wysiłkiem imaginacji przerzucić zmyślone mosty, sprzęgające ponad niezgłębioną przepaścią oba odległe brzegi” (DO, s. 21). Sam zaś Grabiński pisał: „Artysta wychodzi od zdarzeń zwykłych, [...] które w pewnym momencie w sposób nieuchwytny, [...] przestają być normalnymi, [...] i pociągają za sobą nasze jaźnie w świat metafizycznych zjaw i bytów. [...] Nagle znajdujemy się po tamtej stronie rzeczywistości empirycznej [...]. Jesteśmy w świecie metafizycznym"1.

Swoje nowele, jak wiadomo, Grabiński zwykł był wiązać w zamknięte cykle, łącząc je ze sobą na zasadzie tematycznego podobieństwa. W Księdze ognia owym spoiwem tematycznym okazuje się żywioł ognia, a dokładnie „heraklitejska metafizyka ogniowa” (DO, s. 11). Jednakże spośród nowel składających się na ów tom Muzeum dusz czyśćcowych jest opowieścią szczególną i nieco odmienną od pozostałych. To właśnie ta nowela nie pozwala zgodzić się ze zdaniem Marka Adamca, że „Księga ognia to przecież dzieje bezwzględnego tryumfu tego żywiołu. Nie ma przed nim żadnego ocalenia, spopiela wszystko, skazuje ludzi i przedmioty na zagładę [...]. Biada temu, kto zbliży się doń, kto zaufa pozorom bezpieczeństwa”2. Grabiński bowiem w interesującej nas noweli odwołuje się do ognia z zaświatów, przede

1 S. Grabiński, O twórczości fantastycznej. Jej geneza i źródła. (Wstęp do szkicu), „Lwowskie Wiadomości Muzyczne i Literackie" 1928, nr 10, s. 2.

2 M. Adamiec, Cień wielkiej tajemnicy. Rzecz o opowieściach Grabińskiego, „Twórczość” 1982, nr 7, s. 104. 
wszystkim do ognia czyśćcowego, którego ambiwalentna, lecz ostatecznie oczyszczająca moc nie pozwala ujmować go w kategoriach tylko niszczycielskich.

W miarę lektury pojawić się może lekka konsternacja powodowana faktem przedziwnej ideowej kontaminacji, która dokonała się w obrębie tej opowieści. Zadziwiająca metafizyka ognia łączy się w niej z katolicką nauką o duszach w czyśćcu cierpiących, a także z okultystycznymi, spirytystycznymi praktykami nijak nieprzystającymi do wierzeń chrześcijańskich. Jednak czasy, w których żył Grabiński, zaskakiwać mogą po dziś dzień przedziwną osmozą ortodoksji i herezji ${ }^{3}$. Sam tytuł noweli kieruje naszą uwagę w stronę dusz czyśćcowych i czyśćca, których istnienie należy do depozytu wiary katolickiej. Wiadomo, że Grabiński wyrósł w domu głęboko katolickim, jakkolwiek jego twórczość „nie daje z całą pewnością podstawy do zaliczenia jej w poczet tzw. literatury katolickiej” (TLSG, s. 257). Już Hutnikiewicz pisal, że artystę „pociągała sztuka kościelna, liturgia, wreszcie istotna treść kultu, jego dogmaty i symbole", a jego utwory gęsto inkrustowane były kaplicami, postaciami księży, mnichów i zakonnic, dzwonników, pobożnych pątników, pielgrzymów (TLSG, s. 259-264). Z drugiej strony Grabińskiego, człowieka głęboko wierzącego, „cechowała także obojętność dla dogmatu i kanonów ortodoksji” (TLSG, s. 258) ${ }^{4}$. Może zatem pojawić się zarzut, że nie po to Grabiński budował swoje niesamowite, demoniczne światy wpisujące się tak bardzo w specyfikę czasów, w których żył - by teraz tropić je pod kątem prawowierności głoszonych tam prawd i przykładać do nich zestaw dogmatów i wierzeń katolickich. Od razu chcę zatem zastrzec, iż nie będzie mi chodzić o ustalenia, w jakim stopniu odrysowuje się w pisarstwie Grabińskiego teologicznie usystematyzowana, dogmatyczna religijność. Daleka też jestem od chęci mierzenia religijności Grabińskiego zgodnością jego wierzeń z prawowierną nauką ustaloną przez instytucje kościelne i przez nie strzeżoną. Jednakże trudno przeoczyć fakt, iż to nie tyle tradycja i nauki Kościoła katolickiego wkraczają na grunt opowieści Grabińskiego - co sam Grabiński stanął na gruncie i zaanektował na kreacyjne potrzeby swej noweli rubieże od dziesiątek wieków należące do dziedzictwa i wierzeń Kościoła. I zdaje się, że w jego noweli z racji asymilowania i kojarzenia wyobrażeń, idei, symboli chrześcijańskich z okultystycznymi powstała topografia zaświatów miejscami znacznie tracąca na spójności, a momentami nawet na sensowności.

Zaskakująca konstrukacja ideowa Muzeum dusz czyśćcowych rozjaśnia się, gdy przywołamy postać przyjaciela z przemyskich czasów Grabińskiego, którym był Jan Kwolek. Pracował on jako katecheta w miejscowym gimnazjum, nadto, co może stanowić dzisiaj swoiste curiosum, zajmował się problemami mediumizmu i spirytyzmu, „badał je wszechstronnie, z zapałem, aczkolwiek z należytą rezerwą i krytycznie" (TLSG, s. 104). Jednak ksiądz Kwolek stał się nie tylko inspiracją dla powstania postaci księdza Łączewskiego z Muzeum dusz czyśćcowych, okazuje się on bowiem wręcz pomysłodawcą tejże noweli:

${ }^{3}$ Tym co, zdaniem Hutnikiewicza, łączyło rzeczywistości najzupełniej ze sobą niezbieżne - czyli wzmożony ruch katolickich reformatorów czy też rozwój myśli tomistycznej z towarzyszącym im wykwitem najrozmaitszej maści satanistów, teozofów i spirytystów - była chęć wyrwania się za wszelką cenę poza ciasnotę uczuć i myśli, na którą skazywał ludzkość mieszczański wiek XIX. Zob. TLSG, s. 56.

${ }^{4}$ Hutnikiewicz w swojej monografii ukazał złożoną sytuację przebudzenia religijnego epoki, w której przyszło żyć Grabińskiemu, jej rozczarowania i zwątpienia, prowadzące często wprost „pod stopy krzyża”. Zarazem uczony ukazywał, ile w religijnych pozach epoki było "estetycznego snobizmu, więcej upajania się powierzchownego urokami liturgii i odurzania wonią kadzideł, niż szczerej wiary" (TLSG, s. 17). 
Muzeum dusz czyśćcowych rzeczywiście istniało w Rzymie przy kościele Najśw. Serca Jezusowego od r. 1893. W tym to kościele w dniu 2 lipca 1897 r. wybuchł pożar kaplicy, w czasie którego płomień świecy wypalił na oponie jedwabnej, zwisającej przy ołtarzu, jakby figurę biskupa. Proboszcz kościoła, a zarazem opiekun muzeum wydawał specjalne pismo „Le Purgatoire”, poświęcone problematyce związanej z charakterem zbiorów, będących w jego opiece. W numerach 1-3 z r. 1918 wymienionego pisma ukazał się artykuł opisujący dokładnie wspomniane wydarzenie. Numery owe sprowadził ks. Kwolek specjalnie dla Grabińskiego i stamtąd właśnie zaczerpnął pisarz szczegóły do swego opowiadania [TLSG, s. 268-269].

Tytuł interesującej nas noweli odsyła zatem również do realnie i do dziś istniejącego $\mathrm{Mu}$ zeum Dusz Czyśćcowych w Rzymie. Jest to skromne muzeum zajmujące jeden pokój zakrystii kościoła Sacro Cuore del Suffragio. Założył je ojciec Victor Jouët. Ojciec ten zbierał świadectwa, dokumenty i przedmioty mające zachęcić do poświęcenia dla cierpiących dusz czyśćcowych ${ }^{5}$. Dziś znajduje się tam zaledwie 10 eksponatów (relikwii). Wedle wierzeń wiernych to znaki, jakie miały zostawić dusze czyśćcowe: $\mathrm{w}$ większości są to ślady dłoni wypalone w materiałach, modlitewnikach, drewnie, które to ślady dusze zostawiały jako potwierdzenie prawdziwości swego istnienia i jednocześnie znak przypominający, że pojawiały się najczęściej z prośbą o modlitwę. O zgromadzonych tam zbiorach i o duszach czyśćcowych napisał ostatnio książkę holenderski uczony (doktor psychologii i psychoterapeuta), Gerard J. M. van den Aardweg'.

Informacje podane przez Hutnikiewicza na temat rzymskiego muzeum w dwóch miejscach nieznacznie odbiegają od faktów. Pożar w kaplicy wybuchł bowiem podczas jednego z nabożeństw nie w lipcu, lecz w listopadzie 1897 roku. W ogniu, który trawił ołtarz główny (a nie, jak pisze Hutnikiewcz, jedwabną oponę ${ }^{7}$ ), kilka osób - w tym także ojciec Victor - dostrzegło po lewej stronie ołtarza tajemniczą postać cierpiącego człowieka. Wedle przekonań osób tam zgromadzonych była to jakaś dusza czyśćcowa, domagająca się w ten sposób modlitwy w swojej intencji. Nadto po ugaszeniu pożaru w miejscu ukazania się postaci na ścianie powstał smolisty ślad, w którym dostrzec można było wykrzywioną z bólu twarz ${ }^{8}$. Wydarzenie owo stanowiło dla ojca Victora potwierdzenie sensu dzieła rozpoczętego w tym miejscu. Kontynuował zatem swe zainteresowanie duszami czyśćcowymi i zaczął się też zajmować innymi materialnymi śladami „odwiedzin” zmarlych z czyśćca. Sprowadzał te świadectwa z całej niemal Europy, chcąc przekonać wiernych do modlitwy i poświęcenia za cierpiące dusze. Przedmioty, które znalazł i sprowadził, umieszczał na wystawie z dokładnym opisem, gdzie i w jakich okolicznościach pojawiły się tajemnicze znaki. W ten właśnie sposób powstało unikalne i niepowtarzalne Muzeum Dusz Czyśćcowych?.

\footnotetext{
5 Ojciec ten założył także Bractwo Najświętszego Serca Pana Jezusa dla Wybawienia Dusz w Czyśćcu Cierpiących przy wzniesionym przez niego kościele pod tym wezwaniem. Papież Benedykt XV wyniósł je 25 X 1917 roku do godności arcybractwa. Tradycja zakładania stowarzyszeń religijnych mających na celu wspomaganie dusz czyśćcowych przez modlitwę, ćwiczenia pokutne i inne czyny miłosierdzia ciągnie się już od czasów średniowiecza. Zob. K. Kuźmak, Czyściec. Bractwa i stowarzyszenia, [hasło w:] Encyklopedia katolicka, red. R. Łukaszyk, L. Bieńkowski, F. Grygiewicz, t. 3, Lublin 1995, k. 944-946.

6 G. J. M. van den Aardweg, Spragnione dusze. Zjawy z czyśćca. Ich widoczne ślady. Muzeum Dusz Czyśćcowych w Rzymie, tłum. K. Górska-Łazarz, A. Szkudłapska, Warszawa 2008. Muzeum gromadzi zaledwie małą część stygmatów zostawianych przez dusze czyśćcowe, o czym Aardweg pisze w dalszej części książki.

7 Na jedwabnej oponie ślad pozostawia dusza z noweli Grabińskiego.

8 Ślady wypalonej twarzy można oglądać w tym kościele do dziś. W noweli Grabińskiego zarysy twarzy duszy z zaświatów pojawiają się w kościele po prawej stronie ołtarza.

9 Zob. G. J. M. van den Aardweg, op. cit., s. 57-60.
} 
Między eksponatami rzymskiego muzeum a tymi ukazanymi w noweli zachodzi jak najściślejsze podobieństwo - w opowieści Grabińskiego są to także w większości wypalone stygmaty dłoni, choć nie tylko ${ }^{10}$. Podobieństwo owo jest widoczne nawet w rodzaju przedmiotów, na których dusze zostawiały „rozpalony” ślad i w dołączonych do eksponatów opisach. Założycielem owego muzeum również okazuje się ksiądz, późniejszy proboszcz Łączewski, jeden z głównych bohaterów noweli. Mówi on o sobie, że już jako młody kleryk odczuwał szczególną sympatię dla dusz czyśćcowych, obiecując sobie po wyświęceniu otaczać ich pamięć duszpasterską opieką i życzliwością. Gdy został księdzem, zaczął odprawiać częste nabożeństwa w ich intencji. Główny motyw założenia owego muzeum określa ksiądz w słowach: „[... [ moja niezwykła symaptia dla dusz czyśćcowych ma źródła głębsze, może mniej osobiste. Zakładając muzeum, chciałem przede wszystkim zebrać materiał, który by udowodnił niezbicie światu i ludziom, że jest czyściec i kara piekła, że istnieje w ogóle życie pośmiertne duszy [...]”. Po czym dodaje znamienne słowa: „Istnienie czyśćca i piekła jest dogmatem Kościoła" (s. 361) ${ }^{11}$.

Jednakże muzeum założone przez Łączewskiego - w miarę lektury opowieści Grabińskiego - zaczyna coraz bardziej zadziwiać i niepokoić. Coraz bardziej także oddala się od swego rzymskiego pierwowzoru. By wydobyć oryginalność przekonań Grabińskiego na temat dusz przebywających w zaświatach, trzeba najpierw przyjrzeć się owemu pośredniemu stanowi eschatycznemu, jakim jest czyściec.

Historia kształtowania się idei czyśćca jest długa i nie wiąże się bynajmniej z okresem pojawienia się chrześcijaństwa, które dopiero po wielu wiekach wprowadziło go do swojego oficjalnego nauczania, określając mianem prawdy wiary i uznając za nienaruszalny katolicki dogmat ${ }^{12}$. Teksty Starego i Nowego Testamentu nie zawierają jasnej i wyraźnej nauki na jego temat, nie pojawia się tam również sam termin „czyściec”13 - jednakże Pismo Święte ową ideę „przypuszcza i podsuwa” ${ }^{14}$. Idee czyśćca tam zawarte skupiają w sobie wiele elementów z innych kultur i religii. Jacques Le Goff w swym dziele Narodziny czyśćca stwierdza, że po wcześniejszych religiach i cywilizacjach chrześcijaństwo odziedziczyło pewną geografię zaświatów: „[...] spomiędzy koncepcji jednolitego świata umarlych (jak judaistyczny Szeol) oraz idei podwójnego uniwersum po śmierci: jednego przerażającego, a drugiego szczęśliwego, jak Hades i Pole Elizejskie Rzymian, wybrało model dualistyczny. Znacznie go nawet wzmocniło" ${ }^{15}$. Francuski uczony zaznacza zatem, iż czyściec nie jest specyficznie chrześcijańską własnością, ale należy do dziedzictwa wielu kultur, jakkolwiek owe rozmaite tradycje zawierają elementy, które w chrześcijańskiej teologii zostaną uporządkowane i dopracowane, osiągając swoją pełną formę. Ślady idei czyśćca można zatem odnaleźć w tekstach Upaniszady, a także w kulturach Iranu, Egiptu, apokryfach żydowskich, jak też

${ }^{10}$ W muzeum opisanym przez Grabińskiego znajduje się o wiele więcej eksponatów niźli w tym rzymskim. Gromadzi ono także stygmaty dłoni i fragmenty "naszkicowanych“ z grubsza twarzy dusz czyśćcowych pozostawione na wielu chusteczkach, chustkach, fragmentach płótna. Zbiorów dopełnia album i gablota, gromadzące także zdjęcia przedmiotów, na których dusze zostawiły wypalone ślady.

11 Artykuł oparty na edycji noweli Muzeum dusz czyśćcowych z roku 1980 (N). W dalszej części pracy cytaty lokalizuję w tekście głównym w nawiasie.

12 Informacje o czyśćcu referuję głównie na podstawie: Z. Kijas, Czyściec, [w:] idem, Niebo, czyściec, piekło, Kraków 2010, s. 259-448; K. Strzelecka, Czyściec, [hasło w:] Encyklopedia katolicka, k. 939-942.

13 Po raz pierwszy termin ten pojawia się w pismach Hildeberta, biskupa Lavardin († 1134), zostaje przyjęty przez oficjalne nauczanie Kościoła i wprowadzony do dokumentów (Z. Kijas, op. cit., s. 326).

14 Ibidem, s. 286.

15 J. Le Goff, Narodziny czyśćca, tłum. K. Kocjan, Warszawa 1997, s. 8. 


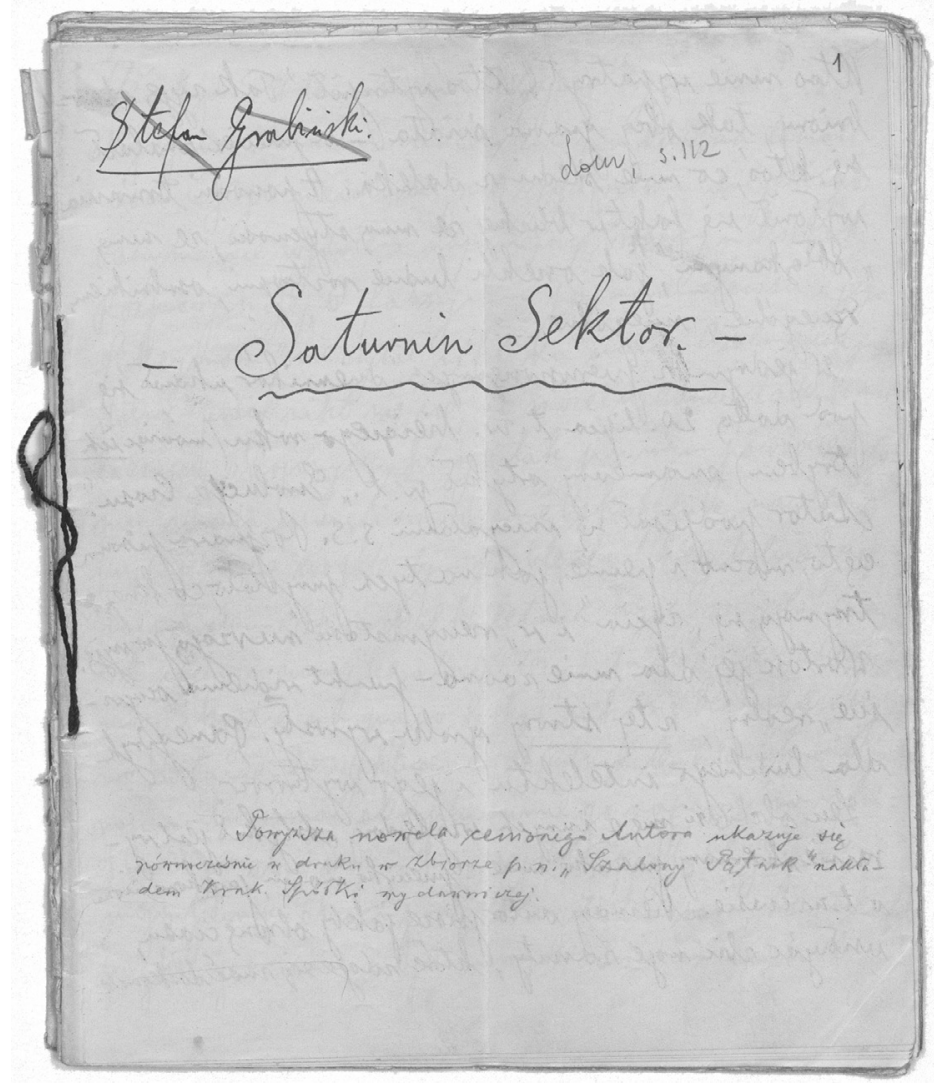

\section{Autograf noweli Saturnin}

Sektor, s. 1-2.

Ze zbiorów Biblioteki

Jagiellońskiej

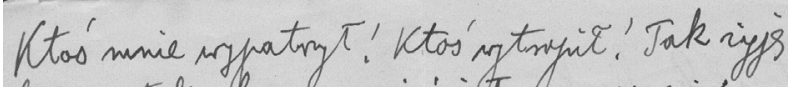
biony, tak sbey snowni siviata - a preciex' nmalact

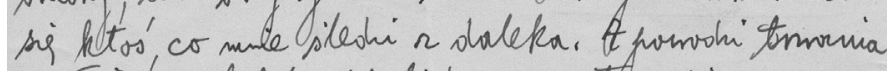

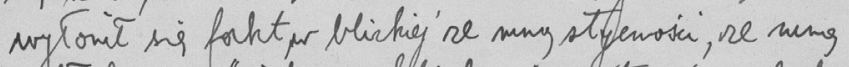

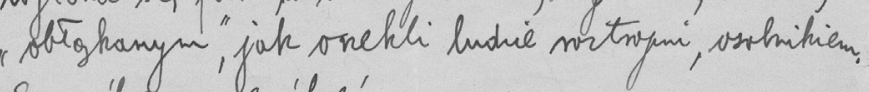
suegilue, suególne,....

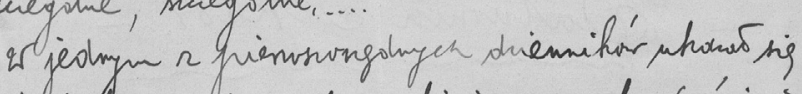

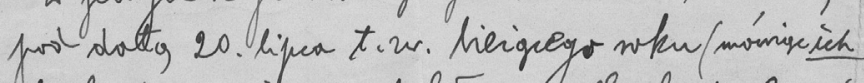

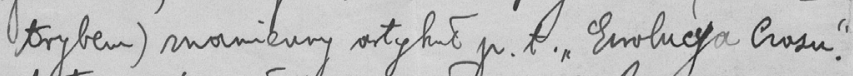

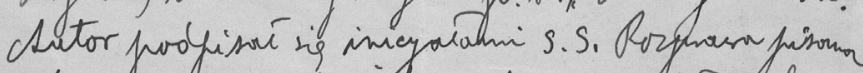

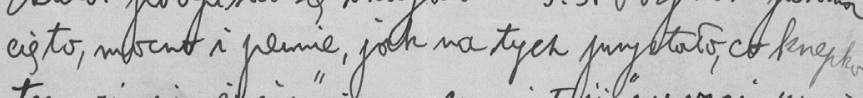

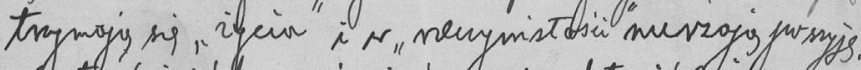

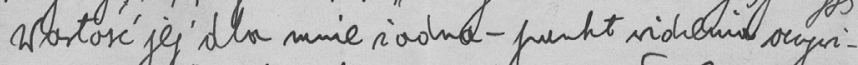

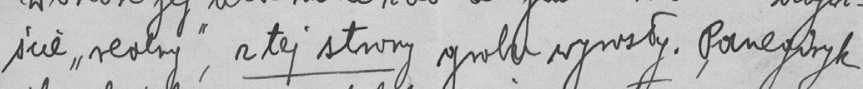
alla hombiegr intelehtu i jegs wy turvor.

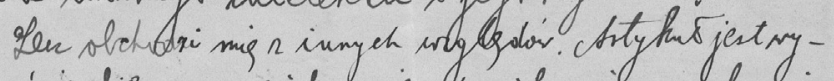

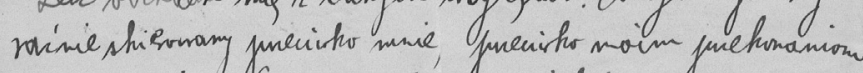

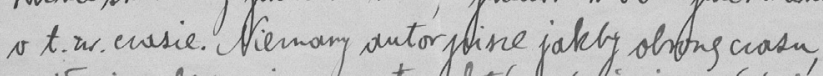

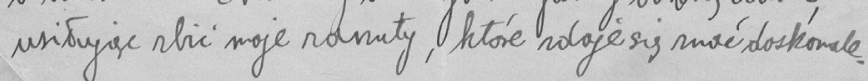

\section{7}

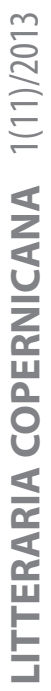


w literaturze Grecji i Rzymu ${ }^{16}$. Biorąc pod uwagę opisy „zaświatów” wspomnianych kultur, łatwo zauważyć pewne wspólne dla nich elementy, które odegrały znaczącą rolę w okresie kształtowania się chrześcijańskiej wizji czyśćca. Należy do nich zaliczyć ból zmieszany z radością, karę i ekspiację oraz oczyszczanie przez ogień.

Dzieje idei czyśćca nakreślone przez Le Goffa ukazują, że idea „stanu pośredniego” odczuwana była w wielu kulturach i religiach starożytnych, które za niewystarczający i zbyt radykalny uznawały manichejski dualizm dobra i zła, nieba i piekła. To pośrednie miejsce w starożytnych wierzeniach opisywane było na wiele sposobów, jakkolwiek (w przeciwieństwie do chrześcijańskiej koncepcji) bliska mu była idea ponownego wcielenia - metempsychoza $^{17}$.

W przeszłości teologom katolickim do opisów czyśćca i opisów postępowania Boga względem dusz tam przebywających często wkradały się rysy prawnicze. Nadmierne pokusy materializacji tego pośredniego stanu eschatycznego prowadzily nie tylko do opisów ognia, ale także lokalizacji czyśćca, jakości jego kar, długości ich trwania etc. ${ }^{18}$ Owe materialne wyobrażenia znajdowały częstokroć odzwierciedlenie także w ikonografii ${ }^{19}$. Bóg objawiał się zatem nie jako Miłość, ale jako surowy Władca, bezwzględnie dochodzący swoich praw. Pobożność ludowa także utożsamiała czyściec z konkretnym miejscem, lokalizując go gdzieś w zaświatach, pojmując jako miejsce wyjątkowo strasznych kar, okrutnych mąk palącego, materialnego ognia, rozgrzanej siarki i ciekłej smoły. Przez wieki kaznodzieje prześcigali się w odmalowywaniu okrucieństwa kar czyśćcowych, opatrując je częstokroć cechami materialności ${ }^{20}$. To doprowadziło w końcu do uzmysłowienia sobie pilnej potrzeby „oczyszczenia czyśćca”, uwolnienia go od cech materialnych, takich jak ogień, czas trwania czy lokalizacja ${ }^{21}$. Wiek XX zmienił bardzo wiele w katolickiej refleksji o czyśćcu. Zaczęto odchodzić od wielu istniejących dotąd praktyk, a także jego konkretnej lokalizacji w zaświatach. Zdecydowanie odrzucono myśl o materialnym ogniu, smole, siarce i innych podobnych formach zadawania bólu ${ }^{22}$. Dzisiejsze stanowisko Kościoła podkreśla, że czyściec „nie jest miejscem, czasem, przestrzenią. Ma formę duchową, której jednak język nie jest w stanie ująć, wyrazić. Stąd właśnie używane przez nas obrazy, materialne terminy, aby przybliżyć, chociaż minimalnie, tę trzecią rzeczywistość”23.

Na tym tle nowela Grabińskiego, przywołująca ogień czyśćcowy, a także piekielny jako ogień jak najbardziej realny, przerażający i wyniszczający - jak go widzi i przy czym upiera się jej bohater proboszcz Łączewski - jest poniekąd ewenementem, ale ukazuje również, jak dalece przekonanie o realności i niszczącej mocy ognia w zaświatach jest wpisane w ludz-

\footnotetext{
16 Zob. Z. Kijas, op. cit., s. 288.

17 Religia irańska, w której uderza wszechobecność ognia, zawiera myśl o przejściu po śmierci przez tenże ogień. Jednakże od chrześcijańskiej koncepcji eschatologii różni ją to, że brak w niej zupełnie sądu jako formy ostatecznego rozliczenia się z poprzedniego życia, gdyż w jego miejsce pojawia się cykliczność, czyli ciągła wędrówka dusz - metempsychoza. Przywołuję ową ideę z racji tego, iż pojawia się ona w noweli Grabińskiego, który nader swobodnie powiązał ją z katolickimi wierzeniami.

18 Zob. Z. Kijas, op. cit., s. 261.

19 H. Wegner, Czyściec. Ikonografia, [hasło w:] Encyklopedia katolicka, k. 943-944.

20 Zob. J. Chélini, Dzieje religijności w Europie Zachodniej w średniowieczu, tłum. I. Wyrzykowska, M. Wyrzykowska, Warszawa 1996.

21 Zob. Z. Kijas, op. cit., s. 359-360. Srogość kar czyśćcowych, na których opisanie „nie masz języka dla ich wypowiedzenia”, opisywała Katarzyna z Genui, zwana „teologiem czyśćca”. Zob. Św. Katarzyna z Genui, Rozprawa o czyśćcu, tłum. A. M. Lubik, Wrocław 1998.

22 Zob. Z. Kijas, op. cit., s. 263.

23 Ibidem, s. 360.
} 
kie wyobrażenia o tych przestrzeniach ${ }^{24}$. Może jednak nieco zadziwiać uporczywość, z jaką proboszcz Łączewski odwowołuje się tylko do tych ojców Kościoła i jego świętych, którzy ogień ów uważali za rzeczywisty i noszący znamiona okrucieństwa ${ }^{25}$. Wizja czyśćca jako materialnego miejsca w zaświatach pojawia się równeż w Boskiej komedii Dantego, którego fragmenty Czyśćca Łączewski cytuje z pamięci. Wiarą w materialność ognia proboszcz stara się wytłumaczyć realność pozostawionych przez dusze czyśćcowe znaków, wyglądających jak wypalone żywym ogniem. Aby poświadczyć rzeczywiste istnienie tego ognia, proboszcz przywołuje naukę św. Augustyna, który jest określany „prawdziwym ojcem czyśćca”. Fascynacja i wiedza proboszcza dotycząca czyśćca jest zatem duża, ale nieco wybiórcza. Św. Augustyn jest autorem sformułowania ignis purgatoris - ognia czyśćcowego ${ }^{26}$, jednakże świętego charakteryzowała raczej niechęć do szczegółowych roztrząsań na jego temat. Wyrażał się o owym ogniu niejasno, rozumiejąc go albo w sensie metaforycznym, albo realnym, nie ulegał natomiast dla niego wątpliwości sam fakt jego istnienia ${ }^{27}$. Augustyn stosownie do rodzaju kar czasowych i wiecznych dokonał rozróżnienia na dwa rodzaje ognia. Jeden z nich przeznaczony był dla potępionych, a drugi - ogień czyśćcowy, płonął tylko po śmierci, a przed zmartwychwstaniem ${ }^{28}$. Na pytanie, dlaczego właśnie ogień, nie jest trudno odpowiedzieć, choć dokładne rozważania owej zaiste bogatej tematyki znacznie przekraczają rozmiary niniejszej pracy. Z natury swej ogień może być bardziej lub mniej niematerialny. Może zostać użyty jako metafora oczyszczenia, wydoskonalenia czy też wzmocnienia materiału - dlatego stanowił bardzo poręczny symbol kar czyśćcowych, w które wpisane jest oczyszczenie, wydoskonalenie i wzmocnienie. Nadto „ogień symbolizuje zarówno moment oczyszczania, jak i spalania, czyli aspekt pozytywny i negatywny”, a taki właśnie charakter ma czyściec: jest on stanem, w trakcie którego dusza ludzka oczyszcza się z kar zaciągniętych na skutek grzechów i zarazem przybliża się na spotkanie z Miłością ${ }^{29}$. Współczesna eschatologia katolicka bardzo powściągliwie wypowiada się na temat trzeciego stanu eschatologicznego. Przyjmuje istnienie czyśćca, powstrzymuje się jednak od precyzyjnej definicji jego natury, pomija milczeniem czas jego trwania, naturę cierpienia, znoszone dolegliwości. Bardziej niż na te aspekty zwraca uwagę na sam fakt, że czyściec istnieje i że jest stanem solidarności pomiędzy żywymi i umarlymi ${ }^{30}$. Do tej solidarności odwołują się dusze czyśćcowe, objawiając się żywym i prosząc o modlitwę. Aby uwiarygodnić swe istnienie i przypomnieć o swej prośbie, zostawiają czasami znaki. Jednym ze stale podtrzymywanych przez Kościół przekonań jest wiara w to, iż to ofiara ołtarza (msza święta) przynosi ulgę duszom czyśćcowym, i wie także o tym bohater noweli Grabińskiego - ksiądz Łączewski, który za owe dusze sprawował msze nawet kilka razy w tygodniu.

Jednak w dalszej części noweli Grabiński snuje opowieść o zaświatowych duszach w sposób, który w wielu miejscach stoi w jawnej sprzeczności z wierzeniami katolickimi

\footnotetext{
${ }^{24}$ Pisarze chrześcijańscy często przedstawiali miejsce oczyszczenia dusz po śmierci jako przestrzeń bardziej przypominającą piekło niż odrębne od nieba i piekła miejsce. Zob. A. Guriewicz, Kultura i społeczeństwo średniowiecznej Europy. Exempla XIII wieku, tłum. Z. Dobrzyniecki, Warszawa 1997, s. 113-115.

${ }^{25}$ Ze stanowiskiem tym polemizuje Proń, który przyjechał zwiedzić muzeum i zdecydował się skatalogować zbiory tam się znajdujące.

${ }^{26}$ Św. Augustyn, Enchiridion, [w:] idem, Pisma katechetyczne, tłum., oprac. W. Budzik, Warszawa 1952, s. 69.

27 K. Strzelecka, op. cit., k. 940.

${ }^{28}$ Warto przypomnieć, że nowelę Grabińskiego opatrują motta: jedno odsyła do ognia piekielnego (z Ewangelii św. Mateusza), a drugie do ognia czyśćcowego (z Boskiej komedii Dantego).

29 Z. Kijas, op. cit., s. 395.

30 Ibidem, s. 448.
} 
o czyśćcu i duszach tam przebywających. Nowela sytuuje się raczej w polu religijności transpersonalnej, eklektycznej i noszącej znamiona synkretyzmu. Nic dziwnego - młodość Grabińskiego przypadła na pierwsze lata XX wieku, które „otwierały tajemnicze i nęcące sezamy Orientu, nurzały się w oparach tak modnej wówczas ówcześnie teozofii i spirytyzmu” (DO, s. 7). Bohaterami interesującej nas noweli są także bratanica proboszcza Hela (medium o wyjątkowych zdolnościach) i psycholog-okultysta Proń (jak o sobie mówi, choć dziś powiedzielibyśmy raczej parapsycholog-okultysta). Już samo zestawienie tych osób uwikłanych w mediumizm - może się zdawać zaskakujące. Trudno bowiem o bardziej nieprawdopodobny mariaż niźli mariaż katolicyzmu z okultyzmem i mediumizmem. Na tak dobraną galerię postaci wpłynęła nie tylko przyjaźń Grabińskiego z księdzem Kwolkiem, parającym się mediumizmem i spirytyzmem. Piętno na tak specyficznie ukształtowanym świecie noweli wycisnęło charakterystyczne dla czasów Grabińskiego podejście do dusz czyśćcowych ze „szkiełkiem i okiem”, będące wypadkową zainteresowań epoki, gdzie usiłowano zbadać „obiektywną, fizykalną egzystencję fantomów” (TLSG, s. 184), czy to były widma i fantomy materializujące się na seansach spirytystycznych, czy też pojawiające się człowiekowi za zgodą Boga dusze czyśćcowe.

Artur Hutnikiewicz w pewnych znamiennych wydarzeniach epoki znalazł odbicie późniejszych pomysłów fabularnych Grabińskiego, więc skrupulatnie je przytoczył. Uczony przywołuje wypadek siostry zakonnej, którą chwyciło pojawiające się widmo przeoryszy i zostawiło na jej ramieniu ślady oparzeń, przechodzące później w pęcherze. Przywołany na miejsce zdarzenia profesor medycyny poddał owe stygmaty naukowemu oglądowi. Hutnikiewicz przytacza przykłady podobnych wypadków:

Siostrze Klarze Izabelli Fornari, ksieni klasztoru św. Klary w Todi, ukazał się zmarly opat z Mantui o. Panzini i na desce, służącej do wyrobu woskowych figurek, $[\ldots]$ zostawił ślad swej dłoni i nakreślił znak krzyża. [...] Siostrze Annie Felicynie Manghini z klasztoru tercjarek franciszkańskich w Foligno ukazała się w r. 1859 zmarła niedawno s. Teresa Małgorzata Gesta i w oczach s. Manghini odcisnęła na drewnianych odrzwiach ślad swej dłoni. Na rozkaz arcybiskupa Foligno otwarto grób zmarkej i skonfrontowano dłoń z jej odciskiem. Pokrywały się zupełnie. Fototypia odcisku ukazała się w czaspiśmie „Luce e Ombra” [TLSG, s. 184].

Wyraźny odblask tych wydarzeń znajdujemy w Muzeum dusz czyśćcowych. Postać siostry Anny Felicji z klasztoru z Foligno jest w noweli przywołana wprost, jednak ukazująca się jej dusza, cała w ogniu, zostawiła inny ślad, ponieważ „na dowód prawdy na drzwiach wypaliła ślad swojej twarzy" (s. 357). Zdecydowanie najczęstszym jednak śladem, jaki konsekwentnie przez wieki zostawiały dusze z czyśćca, jest znak wypalonej dłoni. Zdaniem okultysty Pronia jest to wręcz pewna maniera, o której mówi on z ironią.

Dusze czyśćcowe, czy też w ogólności dusze z zaświatów, są zatem wyjątkowo sposobną płaszczyzną, na której krzyżować się mogą zarówno wierzenia i przekonania katolicyzmu, jak i spirytyzmu ${ }^{31}$. Spirytyści bowiem zwykli „fantomy mediumiczne” utożsamiać z duchami zmarłych (TLSG, s. 189). Wierzenia chrześcijan i spirytystów krzyżują się jednak tylko

${ }^{31}$ Aardweg zwraca uwagę, że wiele katolickich publikacji potwierdza realność pojawiania się żywym dusz czyśćcowych, lecz jakkolwiek są to objawienia udokumentowane i bardziej rzetelne niż to, co znajdujemy na temat objawień zmarłych w literaturze dotyczącej spirytyzmu, poza światem katolickim przeważnie świadectwa owych objawień się ignoruje. Nadto często mylone są z praktykami spirytystycznymi i owe pomyłki mają miejsce także w pseudonaukowej parapsychologicznej literaturze. G. J. M. Aardweg, op. cit., s. 23. 


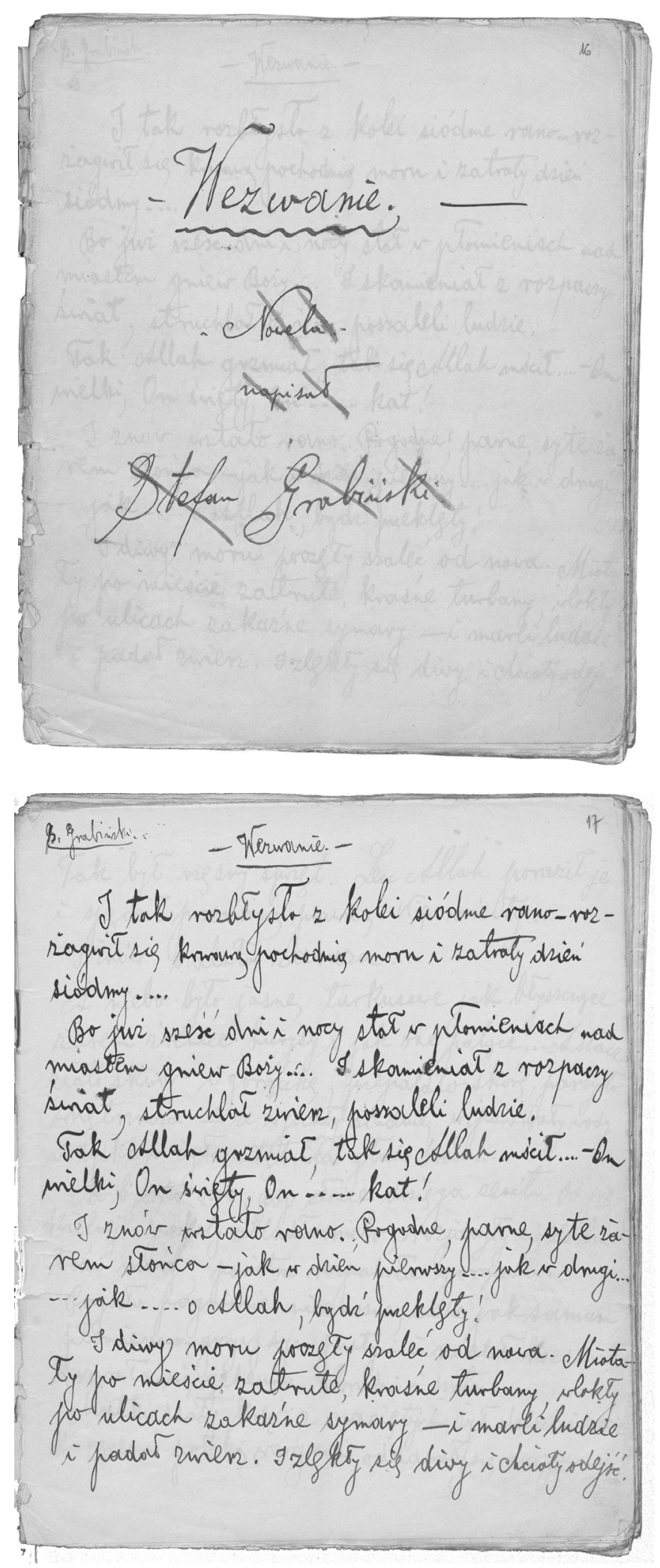

\section{Autograf noweli}

Wezwanie, s. 1-2.

Ze zbiorów Biblioteki

Jagiellońskiej

\section{1}


po to, by się od siebie zdecydowanie oddalić3 ${ }^{32}$. Samo zaś pojęcie okultyzmu stoi w kontekście bardzo wrogim wobec chrześcijaństwa ${ }^{33}$.

Spirytyzm, mediumizm - tak silnie manifestujące się u Grabińskiego - usiłowały m.in. rozwikłać zagadkę istnienia po śmierci i potwierdzić eksperymentalnie nieśmiertelność duszy. Czasy Grabińskiego charakteryzowała wręcz dążność do podboju świata niewidzialnego za pomocą nauki (TLSG, s. 158-207). Szczególne zainteresowania mediumizmem i spirytyzmem przypadły w Polsce na schyłek wieku. Jak pisze Urszula Makowska,

to wszystko, co fascynowało środowisko artystów: „tajemnica bytu”, mądrość Indii, ideoplastia i życie w astralu - nęciło też wielu spoza kręgu bohemy. Miało to być lekarstwem na strach przed śmiercią, na samotność jednostki w nieludzkiej epoce [...]. Równocześnie zaś zajmowanie się tymi sprawami należało podówczas do mody i trudno było bodaj utrzymać się przy opinii wytwornego nie chodząc na seanse spirytystyczne. [...] ów pospolity spirytyzm łączył się więc z mediumizmem czy neobuddyzmem nie tylko w twórczości artystów-mistyków, ale także w życiu mieszczańskich salonów ${ }^{34}$.

Za podstawowy wyróżnik światopoglądu spirytystów przyjmuje się wiarę w istnienie świata pozagrobowego i możliwość kontaktu z duchami zmarłych ${ }^{35}$. Jest to wiara w kontakt bezpośredni - szczególnie z duchami zmarlych, aby otrzymać od nich informację, pomoc czy nawet moc duchową i fizyczną ${ }^{36}$. Z kolei jedna z najbardziej popularnych koncepcji dotyczących mechanizmów pojawiania się duchów zakłada, że wśród ludzi istnieją jednostki szczególnie uwrażliwione, których zdolności predestynują do odbierania i przekazywania sygnałów ze świata zagrobowego. Osoby te znane są pod nazwą mediów ${ }^{37}$.

W XIX wieku zainteresowanie spirytyzmem w krajach kultury europejskiej osiągnęło największy stopień: powstawało tysiące towarzystw, pojawily się setki publikacjii ${ }^{38}$. W Polsce wiek XIX okazał się także prawdziwą eksplozją zainteresowań spirytystycznych, które to fascynacje przeniosły się także w okres międzywojenny ${ }^{39}$. Lwów, tak bliski Grabińskiemu, to miasto, w którym w 1869 roku ukazało się pierwsze w Polsce pismo spirytystyczne

32 Zob. A. Gentili, Chrześcijaństwo i ezoteryzm, tłum. A. Wieczorek, Kraków 1997.

${ }_{33}$ Spirytyzm - jako teoria i praktyka - to jedna z form ezoteryzmu czy okultyzmu, kluczowa dla nich. A. Posacki, Ezoteryzm i okultyzm - formy dawne i nowe, Radom 2009, s. 29. Posacki zwraca uwagę, że okultyzm jest pewnym rodzajem obrazu „wiary“ bazującej na systemie wielu sprawdzonych i niesprawdzonych wierzeń, powiązanych często arbitralnie w jakiś całościowy system rywalizujący zwykle z wizją chrześcijaństwa. Nadto z badań socjologicznych, ale i z analiz filozoficzno-teologicznych jasno wynika, że satanizm i okultyzm to rzeczywistości nierozdzielnie powiązane ze sobą. Antyreligijność okultyzmu przejawia się w jego stosunku do Tajemnicy (odniesienia epistemologiczne: gnoza) oraz w stosunku do Sacrum (odniesienie ontologiczno-aksjologiczne: magia). A. Posacki, op. cit., s. 193, 216-384, 389-390.

${ }_{34}$ U. Makowska, Wiedza tajemna Wschodu. Tendencje okultystyczne w kulturze polskiej na przełomie XIX i XX w., [w:] Orient i orientalizm w sztuce. Materiały Sesji Stowarzyszenia Historyków Sztuki, red. E. Karwowska, Warszawa 1986, s. 336.

${ }_{35}$ A. Zwoliński, Wywoływanie duchów, Radom 2007, s. 9.

36 A. Posacki, op. cit., s. 219. Zob. także: F. Bamonte, Skażenie spirytyzmem. Działanie Złego podczas seansów spirytystycznych, tłum. M. Konrad, Kraków 2005.

${ }_{37}$ K. Olkusz, Materializm kontra ezoteryka. Drugie pokolenie pozytywistów wobec "spraw nie z tego świata”, Racibórz 2007, s. 18. Nekromancja, czyli sztuka wywoływania duchów zmarłych lub konsultowania się z nimi, była praktykowana już w starożytności. W Starym Testamencie tego typu praktyki były zdecydowanie potępiane. Jednakże nawet owo potępienie, przejęte i kontynuowane potem przez chrześcijaństwo, nie spowodowało zaniku zainteresowań i ciekawości względem dusz ludzi umarłych.

38 Zob. A. Posacki, op. cit., s. 223.

39 Zob. A. Zwoliński, op. cit., s. 124. 
„Światło Zagrobowe” ${ }^{\text {*0 }}$. Nic dziwnego, że „Przegląd Katolicki” z roku 1885 wyrażał zaniepokojenie popularyzacją idei spirytystycznych: „Gdzie szerzy się niewiara, tam zabobon i obłęd opanowywać musi umysły; [...] Fakt to charakterystyczny, że w drugiej połowie XIX wieku, owego wieku «oświaty, postępu i nauczania przymusowego» z rokiem każdym wzrasta liczba czasopism spirytystycznych [...]” ${ }^{{ }^{41}}$. Hutnikiewicz pisał, iz „,w ostatnich dziesięcioleciach XIX w. i w pierwszych następnego szał wirujących stolików przybrał rozmiary epidemicznej psychozy”, a wielu zwolenników tej „ezoterycznej pseudoreligii kończyło po prostu w domach obłąkanych”, aż ostatecznie „zmuszony był zabrać głos ex cathedra Kościól. W roku 1917 Kongregacja Św. Officjum powzięła uchwałę zakazującą uczestnictwa w praktykach spirytystycznych” (TLSG, s. 24). Zdaje się, że Grabińskiemu nieobca była świadomość, że stanowisko Kościoła wobec praktyk okultystycznych, których istotą był mediumizm, jest wrogie i nie do pogodzenia z chrześcijańskimi wierzeniami. Gdy bowiem proboszcz Łączewski zastanawia się, w jaki sposób dusze czyśćcowe mogą zostawiać wypalone ślady swej obecności na różnych materiałach, Proń odpowiada zgodnie ze swymi okultystycznymi przekonaniami: „Strona techniczna odcisków, owo ich specjalne zabarwienie i charakter kauteryzacyjny nie przedstawiają większych trudności od tych, jakie pokonują fantomy, rozwiązując problem materializacji, działań telekinetycznych lub ideoplastii” (s. 384). Ta odpowiedź do tego stopnia wzdraga proboszczem, iż szepcze on: Apage satanas! (Precz szatanie!) (s. 364) i dodaje, że on i Proń nie zrozumieją się nigdy. Tak więc ze słów proboszcza mogłoby wynikać, iż tego typu praktyki i wiarę w nie uważa on za szatańskie, a porozumienie $\mathrm{z}$ wyznawcą okultyzmu uznaje za niemożliwe ${ }^{42}$. A jednak mimo tej jasnej deklaracji, w której proboszcz Łączewski stara się odciąć od praktyk okultystycznych, wierzy on w autentyczność tylko tych śladów dusz czyśćcowych, których wiarygodność potwierdziła swymi mediumicznymi zdolnościami jego bratanica. Dla samego zaś Pronia muzeum dusz czyśćcowych jest nie tyle dowodem na istnienie pośredniego rodzaju eschatycznego, jakim jest czyściec, co po prostu „przepięknym i jedynym w swoim rodzaju pomnikiem mediumizmu" (s. 365). Utwierdziły go w tym przekonaniu odlewy gipsowe rąk, nóg, twarzy trzymane osobno w drugiej salce muzeum. Jak okazuje się w trakcie rozwoju akcji, odlewy prawie w ogóle nie nosily śladu wypalonych stygmatów, które są cechami charakterystycznymi zostawianymi przez dusze z czyśćca. To zastanowiło Pronia, a „przyciśnięty” owym spostrzeżeniem proboszcz przyznał stropiony, iż przypuszcza, że „te znaki nie pochodzą od dusz czyśćcowych". Skrywaną tajemnicą proboszcza okazało się, że odlewy trzymane w drugiej salce są „znakami fluidycznych członków, wyciśniętych podczas anormalnych stanów”, w jakie zapada Hela Łączewska. Proboszcz zauważył bowiem, że jego bratanica zapada niekiedy w rodzaj śpiączki, po jakiej odnaleźć można dziwne odlewy ${ }^{43}$. Nie

40 Według relacji z epoki: „jeżeli na jednego mieszkańca Warszawy policzym tylko po jednej godzinie straconej na doświadczeniu ze stołami [...] wypadnie, że w przeciągu tych kilku tygodni zmarnowano 160000 godzin". F. Horain, Stoły wędrujące, Warszawa 1853, s. 47.

${ }^{41}$ Za: K. Olkusz, op. cit., s. 36. XIX-wieczni badacze skłonni byli przychylać się do opinii, że spirytyzm być może jeszcze bardziej rozrósłby się, gdyby nie przywiązanie Polaków do tradycji katolickiej, sprzeciwiającej się praktykom „nekromanckim”. Ibidem, s. 37.

${ }^{42}$ "Okultysta to medium sił nieznanego pochodzenia, niezależnie od tego, jak sam siebie nazywa i jak nazywa te siły. Twierdzi on często, że zna te siły i może je kontrolować. Co nie jest prawdą, gdyż zbyt często pada ofiarą ich zwodniczego i destrukcyjnego działania". A. Posacki, op. cit., s. 398.

${ }^{43}$ Grabiński odwołuje się tutaj zapewne do teorii magnetyzmu F. A. Mesmera. Teorie Mesmera nie miały bezpośrednio na celu stanowić podstaw teorii spirytystycznych czy okultystycznych, jednakże jego liczni uczniowie rozwinęli je w kierunku przeciwnym, tzn. twierdzili, że w odpowiednich okolicznościach (np. w sytuacji 
tracił więc okazji i kiedy bratanicę ogarniała „dziwna senność”, umieszczał obok jej krzesła za zasłoną miednicę z woskiem, gliną lub parafiną, a odlewami powstałymi wskutek tego procederu hojnie „ubogacał” swoje muzeum. Wcześniej przyznał się również, że w pierwszej salce trzyma eksponaty, o których wie, iż są falsyfikatami. Zapytany o to przez Pronia, dobroduszny proboszcz tłumaczy się, że kolekcjonerzy często lubią trzymać w swoich zbiorach też falsyfikaty. O ile zatem księża sprawujący opiekę nad rzymskim Muzeum Dusz Czyśćcowych mieli tendencję do zawężania i weryfikacji zbiorów muzealnych ${ }^{44}$, o tyle ksiądz Łączewski świadomie zapełnial je także eksponatami o podejrzanej autentyczności. Rodzić się zatem mogą poważne wątpliwości, czy przedstawione w noweli miejsce można faktycznie nazywać muzeum dusz czyśćcowych? Zdaje się, że równie prawdziwe okazuje się tu zdanie Pronia, iż muzeum owo jest po prostu pomnikiem mediumizmu.

A jednak przekonanie doktora Pronia, że Hela jest „znakomitym medium dla zjawisk materializacji”, jest dla proboszcza gorszące. Branie zatem, wespół z Proniem, udziału w takich procederach jest dla niego nie do przyjęcia. Dlaczego zatem sam wcześniej pośrednio w nich uczestniczył? Co, w jego mniemaniu, usprawiedliwiało owe zdecydowanie potępiane przez Kościół praktyki i skłaniało do wykorzystywania anormalnych stanów bratanicy? Proboszcz inaczej pojmował chyba ów proceder i inaczej go nazywał. Poprzestawał na naiwnie formułowanym przekonaniu, że Hela jest „ulubienicą duchów”. Można postawić zatem ważne pytanie: jakich duchów? Skoro na pewno nie są to dusze czyśćcowe?

Wedle chrześcijańskich koncepcji medium to „pasywny umysł”, który łatwo może się stać siedliskiem duchów o charakterze demonicznym - jak ostrzegają mistrzowie duchowości ${ }^{45}$. Z samego charakteru technik okultystycznych wynika otwarcie się na złe duchy, a także niebezpieczeństwo destrukcji psychofizycznej ${ }^{46}$. Ważne wydaje się podkreślenie, iż dusze ludzi zmarlych przychodzą wyłącznie za przyzwoleniem Boga, a nigdy na życzenie człowieka ${ }^{47}$. Gdy ten z własnej woli i ciekawości przywołuje duchy zmarłych bądź inne duchy, naraża się na przywołanie demonów, a w skrajnych sytuacjach nawet na opętanie. Nadto „człowiek poniża sam siebie, pozwalając się traktować jako rodzaj mediumistycznego odbiornika sił nieznanego pochodzenia (o nieusuwalnej niepewności źródła informacji), którym nie wiadomo dlaczego ufa, zawierzając często ich autoprezentacji, jak to bywa w przypadku spirytyzmu" ${ }^{3}$. Mediumizm sprzeciwia się zatem personalistycznej godności człowieka, gdzie medium (podmiot) przemieniony zostaje w zwykły przedmiot ${ }^{49}$. O tym, jak ekstremalnie wyczerpujące mogą być seanse dla medium, świadczy chociażby fakt, że Helena podczas nich w pewnych momentach zaczynała tracić niebezpiecznie dużo na wadze. Dochodziło momentami do sytuacji, w której jej postać zacierała się przed oczyma ma-

tzw. snu magnetycznego) można nawiązać kontakt z duchami zmarłych. Wiele zatem elementów zaczerpniętych od Mesmera przeniknęło do spirytyzmu. Zob. A. Posacki, op. cit., s. 223.

${ }^{44}$ Zob. G. J. M. Aardweg, op. cit., s. 60.

45 Zob. A. Posacki, op. cit., s. 227.

46 Ibidem, s. 398

47 Zob. G. J. M. Aardweg, op. cit., s. 33. Według teologii chrześcijańskiej w 95\% duchy zmarłych to demony (zwłaszcza jeśli są aktywnie wywoływane). Zob. A. Posacki, op. cit., s. 233.

48 Ibidem, s. 399. Jak dotąd, na ile można było sprawdzić i zweryfikować, objawienia z czyśćca okazywały się niezmiennie prawdziwe w przeciwieństwie do mętnych i niejasnych zeznań duchów przywoływanych na seansach spirytystycznych. Jest poza tym rzeczą zdumiewająca, że wieści o pojawianiu się dusz z czyśćca cechuje konsekwencja przekazu w ciągu wielu stuleci i niewiele się one różnią od siebie w poszczególnych okresach historycznych. Zob. G. J. M. Aardweg, op. cit., s. 48-49.

49 Zob. A. Posacki, op. cit., s. 226. 
gnetyzera, jakby blednąc i rozwiewając się w przestrzeni. Dopiero wówczas zaniepokojony Proń przerywał eksperyment i przywoływał śpiącą do stanu jawy ${ }^{50}$.

Stanowisko proboszcza Łączewskiego względem procederów mediumicznych dziejących się pod jego dachem jest zatem co najmniej zaskakujące i nieprzejrzyste. Wzdraga się on przed praktykami okultystycznymi, które są dlań szatańskie, ale nie przeszkadza mu to jednocześnie obok autentycznych stygmatów pozostawionych przez dusze czyśćcowe trzymać tych, o których wie, że są odlewami po transach mediumiczych. Zapewne w tych inklinacjach spirytystycznych proboszcza widać odblask fascynacji jego pierwowzorem literackim, jakim był ksiądz Kwolek. W dalszym toku akcji duchowny przymyka oko na to, że pod jego dachem zaczęły się odbywać niemal codziennie seanse spirytystyczne z udziałem Pronia w roli magnetyzera, $\mathrm{w}$ trakcie których jęly pojawiać się fantomy i mary, zawdzięczające swą wyrazistość silnemu wydzielaniu się materii astralnej z ciała medium (Heleny). Warto dodać, iż sposób, w jaki Proń przeprowadzał owe seanse, wskazuje, że nie były one czynione wylącznie dla sensacji i dla zaspokojenia czczej ciekawości, ale miały charakter pełen powagi i z pretensjami do naukowości. Nie darmo Grabiński Pronia nazywa doktorem i wyposaża go we wszelkie znamiona badacza. Ksiądz w owych posiedzeniach nie brał udziału, „unikając widocznie bliższego kontaktu ze sprawą” (s. 367). Z jednej strony nie chciał się wprost sprzeciwić owemu eksperymentowaniu, z drugiej - przyglądał się rozwojowi wypadków z boku i słuchał o nich relacji Pronia.

Niejednoznaczność światopoglądowa proboszcza Łączewskiego oddaje zapewne pewien zamęt ideowy, który mógł panować wszędzie tam, gdzie nie wiedziano ostatecznie, jaką postawę przyjąć wobec mediumizmu. Mediumizm jest bowiem także XIX-wieczną nazwą określającą dziedzinę nauki, zajmującą się zjawiskami w rodzaju telepatii i jasnowidzenia $^{51}$. Niektórzy traktowali ów obszar jako „okultyzm naukowy” (gdyż podobne działania faktycznie mieścily się w XIX wieku w obrębie idei doświadczalnego eksplorowania sfer dotychczas niepoznanych) i sprzeciwiali się kojarzeniu spirytyzmu (uznawanego co najwyżej za grę towarzyską) z mediumizmem, mającym pretensję do bycia gałęzią nauki. Czasopismo „Ateneum” zamieściło w 1889 roku znamienny artykuł Władysława Kozłowskiego pt. Spirytyzm, w którym czytamy:

Nie da się zaprzeczyć, że rozwój nauk przyrodniczych [...] musiał wywołać odpowiednie zmiany w zapatrywaniach i wierzeniach, odnoszących się do świata nadprzyrodzonego. Wiara w świat nadprzyrodzony, tracąc swą podporę w religii, zmuszona jest jej szukać gdzie indziej. Jakoż znajduje ją w pewnych faktach, nacechowanych cudowością, [...] na których opiera się tak zwany spirytyzm $^{52}$.

Artykuł zaś zamieszczony w „Niwie” w 1895 roku zwracał uwagę na naukowy charakter mediumizmu i wskazywał wręcz na konieczność badania zjawisk, takich jak hipnotyzm, magnetyzm, somnambulizm, których analizowanie „nie stoi bynajmniej w sprzeczności z nauką Kościoła”33.

${ }^{50}$ Uczeni XIX-wieczni zwracali uwagę, że częste wprowadzanie w trans powoduje skutki uboczne, nie tylko w planie mentalnym, lecz również fizycznym. Zob. K. Olkusz, op. cit., s. 154.

${ }^{51}$ Zob. ibidem, s. 21.

52 Za: ibidem, s. 23.

53 Ibidem, s. 22. 


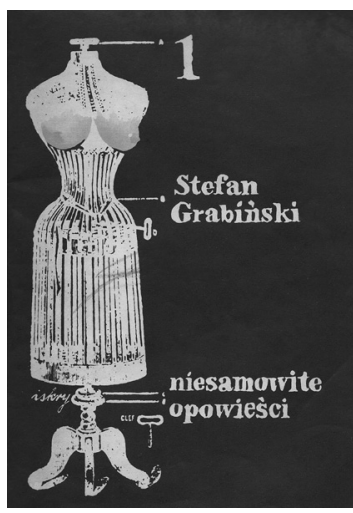

S. Grabiński, Niesamowite opowieści, cz. 1,

Państwowe Wydawnictwo Iskry, Warszawa 1981

Mediumiczność przejawia się w różnych postaciach i jest źródłem różnorodnych zjawisk. Począwszy od tych dotyczących zmian psychicznego i fizycznego stanu człowieka wcielanie się weń „duchów” (aż po opętanie), przez widzenie z odległości, jasnowidzenie, wyczuwanie śladów pozostawionych przez psychikę ludzką w materii martwej (psychometria), wyczuwanie zjawisk i rzeczy przeszłych i przyszłych, samoznieczulanie, zastępowanie jednych zmysłów innymi, bilokację i wytwarzanie sobowtórów, wydzielanie przez medium nowej materii jako „ektoplazmy” (w tym wytwarzanie „zjaw” postaci ludzkich lub zwierzęcych). Ponadto obejmuje także: zjawiska dotyczące nadnormalnego działania organizmu ludzkiego na materię i energię poza organizmem własnym („magnetyzowanie”), dematerializację i rematerializację ciał, zjawiska poruszania lub unoszenia przedmiotów, dokonywanie na odległość różnych czynności, jak np. pisanie, czynienie odcisków w masie parafinowej, różnego rodzaju promieniowanie (działanie na kliszę fotograficzną) oraz wiele innych zjawisk elektrycznych i magnetycznych ${ }^{54}$. Gdy przyglądamy się możliwościom Heli, nie dziwi nas zdumienie, $w$ jakie wprawiały one eksperymentującego z nią Pronia. Hela potrafila $w$ trakcie swych anormalnych stanów powodować nie tylko powstawanie odlewów w parafinie; wyrazistość materii astralnej wydzielanej z jej ciała była tak silna, że Proń zdecydował się fotografować ową „galerię powstających mar i fantomów” (s. 367, por. TLSG, s. 182-183). Jakby tego było mało:

Wkrótce obok materializacji ujawniły się u medium zdolności psychometryczne. Panna Helena nie tylko odczytywała pismo zamknięte w kopercie i odgadywała przedmioty ukryte w drewnianej lub metalowej szkatułce, lecz umiała też sięgnąć intuicją wstecz, do przeszłości, i opowiedzieć ich historię; wystarczyło tylko podczas transu przyłożyć je w tym celu do czoła lub serca medium [s. 367].

Zdolności Heleny skłoniły Pronia do ponownej rewizji eksponatów znajdujących się w muzeum dusz czyśćcowych, by oddzielić te, które zostawiły dusze czyśćcowe, od tych o podejrzanej wartości lub fałszywych. Okultysta rewizję ową poczynit, odwołując się do zdolności psychometrycznych medium, aby dojść do pełnego szacunku przekonania, iż „znaki, uznane przez Helenę za autentyczne, stały się dokumentami pierwszorzędnymi, z którymi należało się liczyć poważnie" (s. 368). Dochodzi tutaj zatem do nieco kuriozalnej sytuacji: autentyczność znaków pozostawianych przez dusze czyśćcowe potwierdza swoimi mediumicznymi zdolnościami Helena, urastająca poniekąd tym samym do rangi autorytetu sygnującego prawdziwość czyśćca i dusz czyśćcowych. Jak pamiętamy, proboszcz Łączewski także za prawdziwe uznawał tylko te stygmaty pozostawione przez dusze czyśćcowe, których autentyczność potwierdziła Helena. O ile nie dziwią nas mediumiczne fascynacje okultysty Pronia, dla którego bardziej seanse niż nauka chrześcijańska są potwierdzeniem istnienia dusz czyśćcowych, o tyle stanowisko księdza, odwołującego się do weryfikacji medium, jest co najmniej konsternujące i stanowi świadectwo tego, iż na przełomie XIX i XX wieku dla wielu eksperymenty mediumiczne mogły stanowić poważniejszą rękojmię istnienia zaświatów niż przekonania wynikające z wiary chrześcijańskiej. Hutnikiewicz pisał:

Grzeszny kardynał Rufredo [... ], aby zaświadczyć o istnieniu czyśćca i piekła i o swej własnej zasłużonej pokucie wciela się po kilku wiekach w postać ks. Łączewskiego, który zakłada jedyne

${ }^{54}$ A. Zwoliński, op. cit., s. 61. 
w swoim rodzaju muzeum okazów stygmatoplastii, zwłaszcza znaków o charakterze kauteryzacyjnym. Te ślady i odciski, wypalone na rozmaitych przedmiotach przez dusze pokutujące, mają udowodnić „niezbicie światu i ludziom, że jest czyściec i kara piekła, że istnieje w ogóle życie pośmiertne duszy” [TLSG, s. 196].

Tymczasem - na co zresztą powoływał się proboszcz Łączewski - wiara w czyściec jest dogmatem Kościoła. Należy do depozytu wiary i nie potrzebuje potwierdzania na seansach mediumicznych. Nie dość na tym - Kościół wyraźnie sprzeciwia się potwierdzaniu przez wiernych wiary $\mathrm{w}$ zaświaty przez próby inwazyjnego kontaktowania się z duchami. Biblia mówi o tym w sposób aż nadto wyraźny:

Nie znajdzie się pośród ciebie nikt, kto by [...] uprawiał zaklęcia, pytał duchów i widma, zwracał się do umarlych. Obrzydliwy jest bowiem dla Pana każdy, kto to czyni. Z powodu tych obrzydliwości wypędza ich Pan, Bóg twój, sprzed swego oblicza. [...] Te narody bowiem, które ty wydziedziczysz, słuchały wróżbitów i wywołujących umarłych. Lecz tobie nie pozwala na to Pan, Bóg twój [Pwt 18, 10-12] $]^{55}$.

Nie tylko judaizm i katolicyzm, ale i protestantyzm, a także prawosławie stanowczo potępiają spirytyzm, odwołując się do Starego Testamentu (Pwt 18, 10-14), który zakazuje wszelkich prób kontaktu ze zmarlymi. To samo podtrzymują Nowy Testament i wszyscy ojcowie Kościoła.

Najsłynniejszym bodaj polskim dziełem o przywoływaniu dusz zmarłych są Mickiewiczowskie Dziady. Mimo szacunku do obrzędu wywoływania duchów przodków, jest w tym dziele także obecna świadomość, iż Kościół sprzeciwia się owemu obrzędowi. Trzeba też przyznać, że IV część Dziadów, gdzie adwersarzami są Ksiądz i Pustelnik (Gustaw), przypomina nieco adwersarzy, jakimi byli proboszcz Łączewski i doktor Proń. Proboszcz Łączewski sprzeciwiający się (aczkolwiek słabo) wywoływaniu duchów (w czym przypomina postawę Mickiewiczowskiego Księdza) ulega ostatecznie argumentacji Pronia - jak się zdaje - wyraziciela poglądów samego Grabińskiego. Zwycięstwo ideowe Pronia jest oczywiste i bezdyskusyjne, tak jak bezdyskusyjne okazały się przewaga i racje światopoglądowe Gustawa. Oto bowiem w trakcie kolejnego seansu Pronia dusza zmarłego nagle proboszcza Łączewskiego poświadcza prawdziwość metempsychozy, co stoi w jawnej sprzeczności z wiarą chrześcijańską, a sam Proń urasta poniekąd na zbawiciela uwięzionej w ciele Łączewskiego kardynalskiej duszy. Motyw preegzystencji i reinkarnacji był jądrem i osnową tematyczną wielu utworów Grabińskiego ${ }^{56}$. Trudno jednak powiedzieć, dlaczego teorię o wędrówce dusz potwierdza w noweli akurat ksiądz katolicki, który w trakcie lektury okazuje się wcieleniem, inkarnacją „pełnego wyuzdania i grzesznego Lorenza Rufredo - kardynała z czasów Aleksandra VI”. Wiadomo na pewno, że chrześcijańskiej wiary nie sposób powiązać z teo-

${ }^{55}$ W Księdze Kapłańskiej także padają wyraźne słowa potępiające kontaktowanie się z duchami: „Także przeciwko każdemu, kto zwróci się do wywołujących duchy albo do wróżbitów, aby uprawiać z nimi nierząd, zwrócę oblicze i wyłączę go spośród jego ludu" (Kpł 20, 6). Zakaz spirytyzmu we wszelkich formach istnieje też wyraźnie w Katechizmie Kościoła Katolickiego (KKK 216-217).

${ }^{56}$ Warto tutaj przypomnieć, iż Grabiński był sympatykiem genezyjskiej filozofii Słowackiego, w której tak ważkie miejsce zajmowała idea metempsychozy.

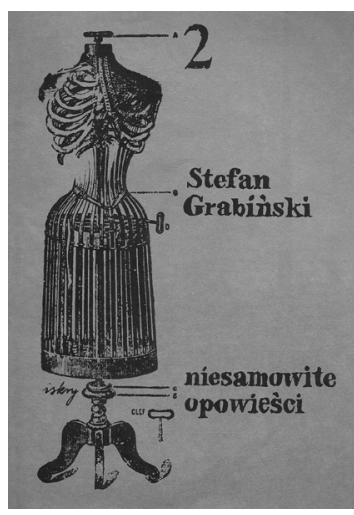

\section{S. Grabiński, Niesamowite opowieści, cz. 2,} Państwowe Wydawnictwo Iskry, Warszawa 1981 
riami reinkarnacji ${ }^{57}$. Ale, jak pisał Hutnikiewicz o czasach Grabińskiego: „Tych, którym nie wystarczało chrześcijaństwo i mistyka średniowiecza, spirytyzm czy mediumizm, urzekała z kolei filozofia Wschodu” (TLSG, s. 25).

Zarys postaci owego kardynała pojawił się w 1870 roku Łączewskiemu, gdy ten modlił się w kościele za dusze umarlych. O północy - tradycyjnej porze pojawiania się duchów kopcąca na ołtarzu świeca pozostawiła w obecności Łączewskiego na wiszącym nieopodal jedwabiu zarysy tej dziwnej, kardynalskiej postaci. Ów „portret” - nazwany przez proboszcza „biskupem” - stał się zawiązkiem muzeum dusz czyśćcowych. I to ten właśnie eksponat interesował Pronia - rzecz znamienna - najbardziej. Helena podczas kolejnego seansu spirytystycznego - wykorzystana przez magnetyzera bez swojej zgody i wbrew jej woli do psychometrycznego badania owego wizerunku ${ }^{58}$ - przyczyniła się do zmaterializowania fantomu kardynała Rufredo. Obserwując go, nie mamy wątpliwości, że jest to dusza przywołana z piekła. Twarz kardynała nazwana jest diaboliczną, oczy mają wyraz „piekielnego przerażenia", słowa wyrywające się z ust medium to: Vexilla regis prodeunt inferni! (Oto postępują naprzód proporce króla piekieł!) i znamienne: Cremaberis igne aeterno! (Ogniem wieczystym trawiony będziesz!). Ten przerażający duch kardynała przechodzi jednak metamorfozę w niebiańską i pełną słodyczy postać księdza Łączewskiego. W dalszym ciągu widzimy jak - w nieco dewocyjnej konwencji - dusza proboszcza unosi się na klęczkach i ze złożonymi na piersiach rękoma miast wędrować do nieba (którego to kierunku byśmy się spodziewali) rozpływa się w przestrzeni. Zapewne Grabiński w ten nieco naiwny i obrazowy sposób przedstawia nam - zgodne z teoriami wędrówki dusz - przekonanie, że dusza wcielająca się w kolejne byty osiąga ostatecznie stan nirwany, czyli niebytu, całkowitego wygaśnięcia ludzkiego istnienia złożonego z materii i ducha. Trudno zatem ów barwnie opisany koniec żywota proboszcza zaliczyć do chrześcijańskiego repertuaru artes moriendi i nic tu nie pomoże fakt, że Łączewski umiera z ustami na krucyfiksie.

Zdawać by się mogło, iż niesamowita akcja noweli ma zatem zakończenie szczęśliwe. Oto grzeszny kardynał Rufredo (wcześniejsze wcielenie proboszcza) odpokutował w ciele poczciwego proboszcza Łączewskiego, a seans mediumiczny zainicjowany przez okultystę przyczynia się do końca mąk piekielnych duszy grzesznego kardynała. Jednakże zaraz potem zaczynają się cisnąć pytania, na które trudno - jak sądzę - dać jednoznaczną i wyczerpującą odpowiedź. Dlaczego portet duszy z piekła rodem (czyli potępionego kardynała) utworzony przez świecę na jedwabiu posłużył jako zawiązek dla muzeum dusz czyśćcowych? Przecież winien raczej posłużyć jako eksponat dla muzeum dusz potępionych - jeśli takowe w ogóle ktokolwiek miałby ochotę zakładać! Mamy tu zatem do czynienia z mimowolnym wypaczeniem idei zakładania muzeum dusz czyśćcowych. Dlaczego ów najważniejszy dla proboszcza Łączewskiego eksponat był trzymany w drugiej salce muzeum, w której - jak pamiętamy - znajdowały się eksponaty pozyskiwane za sprawą mediumizmu? Wszak ów duch pojawił się w kościele samoczynnie, nie będąc wzywany na żadnym seansie. Jak pogodzić katolickie przekonanie o tym, iż dusze przebywające w piekle są potępione na wieki, z faktem, że katolicki dostojnik - kardynał Rufredo - z tego piekła wydostaje się za sprawą „translokacji” w duszę proboszcza Łączewskiego? Na tym nie koniec pytań i wątpli-

57 J. Sachs wyszczególnił osiem aspektów chrześcijańskiego rozumienia zbawienia, które stoją w wyraźnej sprzeczności z teorią reinkarnacji. Za: Z. Kijas, op. cit., s. 437.

${ }_{58} \mathrm{~W}$ wieku XIX podkreślano, „że nawet najbardziej podatne na usypianie osoby nie wykonają polecenia sprzecznego z ich etyką lub zagrażającego życiu". K. Olkusz, op. cit., s. 156. 


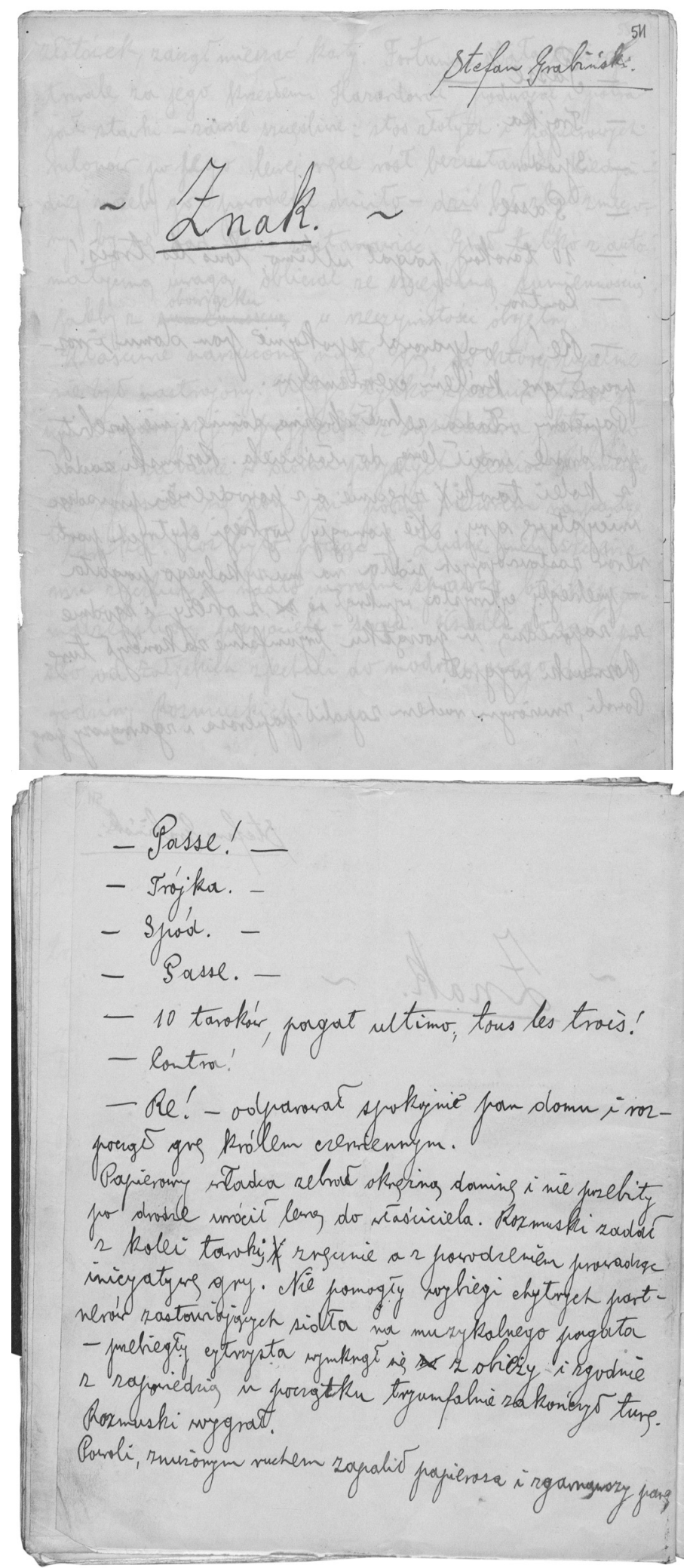

\section{Autograf noweli Znak,}

s. 1-2.

Ze zbiorów Biblioteki

Jagiellońskiej

\section{9}

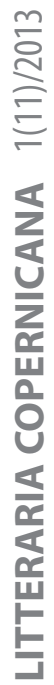


wości. Czemu Grabiński w wielu miejscach przywołując katolicką naukę o czyśćcu - w której tak istotne jest przekonanie o możliwości skrócenia kar dusz cierpiących w zaświatach przez modlitwę i wstawiennictwo osób żyjących - uwalnia następnie duszę cierpiącą nie za sprawą tychże modlitw i wstawiennictwa, ale za sprawą metempsychozy? Chrześcijańska koncepcja czyśćca i reinkarnacja to dwie zupełnie obce sobie koncepcje człowieka, historii, nieśmiertelności i zbawienia ${ }^{59}$. Trzeba przyznać, że niespójności światopoglądowe noweli wynikać mogą z prostego faktu, iż nie sposób połączyć chrześcijańskiej eschatologii ze staroindyjską kosmogenezą i mediumizmem.

Irzykowski twierdził, że Grabiński „nie mogąc wywoływać duchów pisał je”60. Hutnikiewicz z kolei przypominal, iż cała twórczość Grabińskiego wyrosła z pytania: czy istnieje życie poza granicą śmierci? I właśnie to pytanie, zdaniem uczonego, skłoniło pisarza do studiów nad magią i czarnoksięstwem, do wertowania dzieł parapsychologów, okultystów, spirytystów, do przeglądania potężnych „dokumentarnych foliałów towarzystw metapsychicznych, do zaczytywania się w księgach starych demonologów" ${ }^{61}$. Nie dziwi zatem, że Księga ognia została nazwana księgą heretycką ${ }^{62}$. „Traktat” o duszach czyśćcowych Grabińskiego ostatecznie okazuje się traktatem heretyckim. A ogień, do którego z takim przekonaniem odwołuje się Łączewski, „nie powinien być ujmowany jako główny symbol tej przestrzeni w zaświatach, gdyż jest wyrażeniem metaforycznym i nie daje podstawy do określenia rodzaju kar czyśćcowych”63. A jednak postać księdza Łączewskiego poświadcza paradoksalnie, iż owe „nieprawowierne” studia Grabińskiego nie potrafily wyrugować z niego do końca wiary w zaświaty chrześcijańskie. Sam zaś pomysł na nowelę zrodził się nie ze studiów nad księgami magii i czarnoksięstwa, ale nad pismem wydawanym przez księdza prowadzącego w Rzymie Muzeum Dusz Czyśćcowych.

Topografia zaświatów z noweli Grabińskiego przypomina starą prawdę, że od niepamiętnych czasów towarzyszyła ludziom symbioza różnych porządków, przejawiająca się częstokroć w przyznaniu np. czarom skuteczności na równi z sakramentami ${ }^{64}$. Nowela Grabińskiego wpisuje się nie tylko w ducha czasów, w których żył. Wpisuje się znakomicie także w specyfikę czasów współczesnych. Podobno kilka lat temu rozważano nawet zamknięcie rzymskiego Muzeum Dusz Czyśćcowych dlatego, że częściej od pobożnych wiernych przychodzili tu fascynaci zjawisk paranormalnych ${ }^{65}$. Opowiadanie Grabińskiego przypomina także, iż pojawianie się duchów zawsze w człowieku budziło strach, kojarząc się zwykle ze śmiercią lub jakimś rodzajem zła moralnego. Nieprzypadkowo zatem świat duchów kojarzy się z demonologią, a także z magią; tak pojęte pierwiastki magiczno-spirytystyczne mylone

${ }^{59}$ Zob. Z. Kijas, op. cit., s. 441.

${ }^{60}$ K. Irzykowski, Słoń wśród porcelany. Lżejszy kaliber, Kraków 1976, s. 398.

${ }^{61}$ Badacze podkreślają, że dla Grabińskiego przyjmującego koncepcję metempsychozy „śmierć traciła swą grozę, skoro nie kryła się za nią pustka i nicość, lecz czekało nowe, może bogatsze, może pełniejsze jeszcze i wspanialsze życie" (TLSG, s. 195-197). Dziś nie da się już obronić tych nadmiernie psychologizujących opinii badaczy. Bardziej prawdopodobne jest tutaj, że metempsychoza stanowiła po prostu niezwykle interesujący motyw literacki. Była ona także sygnałem przynależności do grupy prezentującej „nowoczesne" $i$ "modne poglądy", stawała się także "wartościowym tworzywem literackim, jako podlegające analizie zjawisko światopoglądowe". K. Olkusz, op. cit., s. 177.

62 Zob. M. Adamiec, op. cit., s. 104.

${ }_{63}$ Zob. K. Strzelecka, op. cit., k. 939.

${ }^{64}$ E. Kasperski, Religijność a literatura romantyczna, [w:] Religie i religijność w literaturze i kulturze romantyzmu, red. E. Kasperski, O. Krysowski, Warszawa 2008, s. 375.

65 Zob. M. Wielek, Muzeum Dusz Czyśćcowych, "List” 2008, nr 10. Dostępny również na stronie: http://www. opoka.org.pl/biblioteka/T/TD/list_10_08_smierc2.html. 


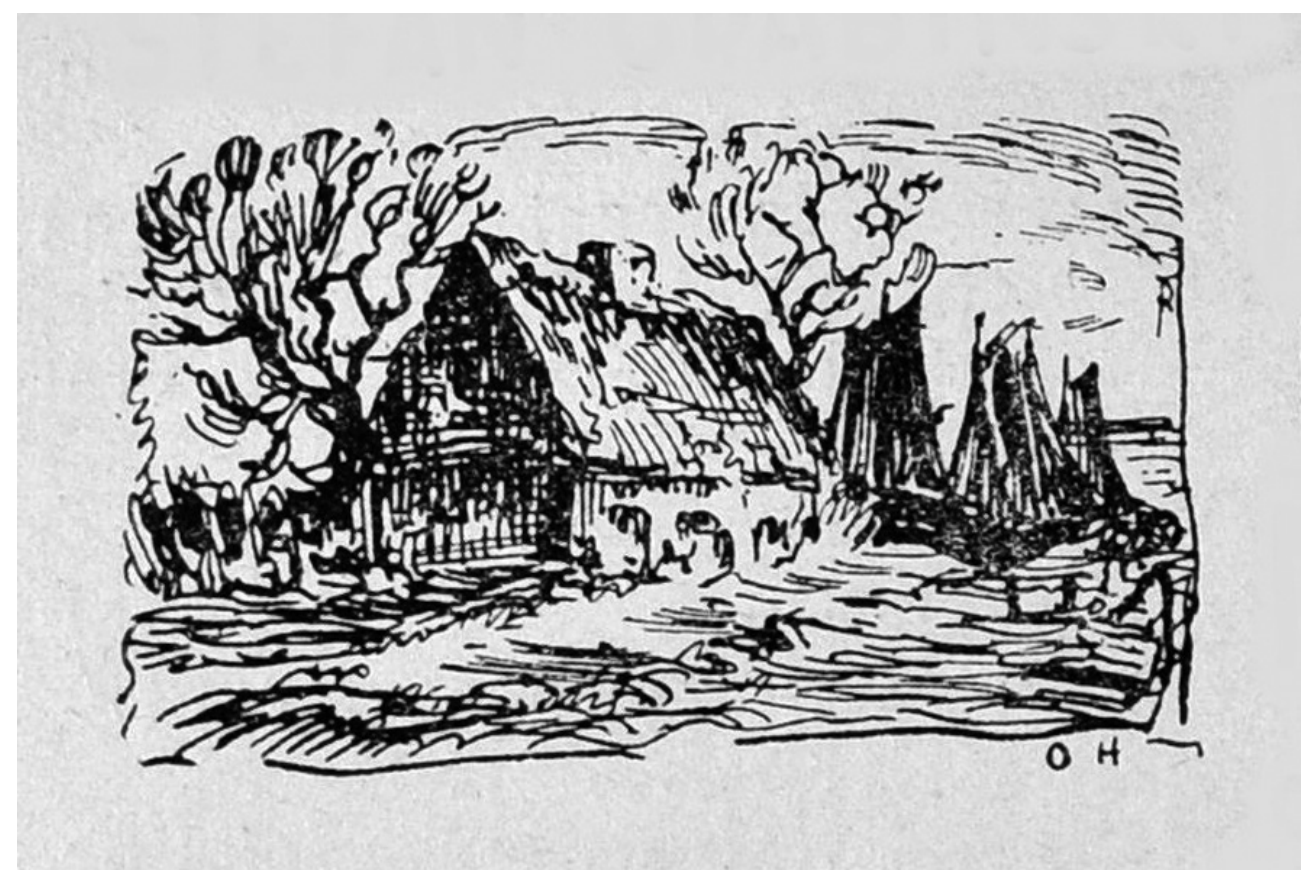

Ilustracja do noweli Przypławek Jana Mrocha. Opowieśćz przystrądzia, "Gryf" 1933, nr 3, rys. NN

bywają po dziś dzień ze sferą sacrum, mimo iż reprezentują pewną inwersję tego, co święte, lub wręcz manipulację świętością ${ }^{66}$. Rejony herezji, z takim rozmachem nakreślone przez Grabińskiego, nie budzą specjalnie naszej grozy ani zgorszenia. A istnienie czyśćca i dusz czyśćcowych jest nadal dogmatem Kościoła, pomimo tego, że epoka Grabińskiego nie udowodniła tego eksperymentalnie.

Mało kto pamięta dzisiaj potępioną duszę kardynała Rufredo. Bardziej chyba zapada bowiem w pamięć słynna nauka i przestroga, którą wygłosił duch Złego Pana z II części Mickiewiczowskich Dziadów:

Do nieba?... Bluźnisz daremnie... [...]

Tak, muszę dręczyć się wiek wiekiem,

Sprawiedliwe zrządzenia Boże!

Bo kto nie był ni razu człowiekiem,

Temu człowiek nic nie pomoże ${ }^{67}$.

${ }^{66}$ Zob. A. Posacki, op. cit., s. 234.

${ }^{67}$ A. Mickiewicz, Dziady. Część II, [w:] idem, Dzieła. Wydanie Rocznicowe, t. 3, Dramaty, oprac. Z. Stefanowska, Warszawa 1999, w. 211; 323-326. 